\title{
Fish welfare based classification method of ocean current speeds at aquaculture sites
}

\author{
Kristbjörg Edda Jónsdóttir ${ }^{1, *}$, Malthe Hvas ${ }^{2}$, Jo Arve Alfredsen ${ }^{1}$, Martin Føre ${ }^{1,3}$, \\ Morten Omholt Alver ${ }^{1,3}$, Hans Vanhauwaert Bjelland ${ }^{3}$, Frode Oppedal ${ }^{2}$
}

${ }^{1}$ Department of Engineering Cybernetics, Norwegian University of Science and Technology, 7491 Trondheim, Norway

${ }^{2}$ Research Group of Animal Welfare, Institute of Marine Research, 5984 Matredal, Norway

${ }^{3}$ SINTEF Ocean, 7465 Trondheim, Norway

\begin{abstract}
A major trend in marine aquaculture is to move production to more exposed sites with occasionally rough ocean current events. However, it is unclear whether fish will thrive in these extreme environments, since thorough descriptions of ambient current conditions with regards to fish welfare is lacking. In the present study, ocean current data were collected using acoustic Doppler current profilers at 5 exposed sites along the Norwegian coast over minimum periods of 5 mo. To evaluate welfare risks, current data was compared to known limits of swimming capabilities, such as onset of behavioural changes and critical swimming speeds $\left(U_{\text {crit }}\right)$, of Atlantic salmon Salmo salar and lumpfish Cyclopterus lumpus. Specifically, at each site, current speeds were classified into 6 categories based on expected impact on swimming behaviours of Atlantic salmon, and duration of currents within each category were inspected using a homogeneous and non-homogeneous criterion for the water column. Current speeds were then compared with projected $U_{\text {crit }}$ at relevant temperatures and fish sizes of Atlantic salmon and lumpfish. Furthermore, a detailed characterization of extreme events at the most exposed site was performed. Of the 5 locations, only 1 exceeded the $U_{\text {crit }}$ of Atlantic salmon, while all sites featured currents above $U_{\text {crit }}$ of lumpfish for up to $33 \mathrm{~h}$ at a time. These results suggest that responsible Atlantic salmon farming is possible at sites considered exposed, while lumpfish should be restricted to more sheltered environments. The presented method can be applied for other aquaculture fish species if adequate data are available.
\end{abstract}

KEY WORDS: Atlantic salmon - Lumpfish $\cdot U_{\text {crit }} \cdot$ Exposed farming Ocean current speed Swimming behaviour $\cdot$ Sea cage environment

\section{INTRODUCTION}

With the continuing expansion of the marine aquaculture industry and a decrease in available sites in nearshore areas due to spatial conflicts and competing claims, there is a growing interest in moving new production sites to more exposed coastal and offshore locations (e.g. Holmer 2010, Bjelland et al. 2015, Gentry et al. 2017). These sites are exposed to harsher wind, wave and current conditions (Holmer 2010, Bjelland et al. 2015). The stronger water currents may be advantageous, as higher water ex-

*Corresponding author: kristbjorg.jonsdottir@ntnu.no change rates result in larger nutrient assimilation capacity, higher levels of dissolved oxygen and generally better water quality (Johansson et al. 2007, Holmer 2010, Klebert et al. 2013, Gentry et al. 2017). However, stronger water currents may induce excessive loads on the farm structure and large net deformations, resulting in challenging conditions for farming operations (Lader et al. 2008, Kristiansen \& Faltinsen 2012, Bjelland et al. 2015, Klebert et al. 2015, Gansel et al. 2018). The currents may also be evaluated from a fish-welfare perspective, the primary concern being how the magnitude, duration

(C) The authors 2019. Open Access under Creative Commons by Attribution Licence. Use, distribution and reproduction are unrestricted. Authors and original publication must be credited. 
and frequency of strong current events affect behaviour, growth, stress and risks of mortality (Johansson et al. 2014, Solstorm et al. 2015, Remen et al. 2016, Hvas \& Oppedal 2017).

The response of farmed fish to ocean currents may be expressed as behavioural changes. Specifically, the group structure of Atlantic salmon Salmo salar in commercial farms and experimental setups is observed to change from circular schooling to 'standing' on the current, i.e. remaining stationary while swimming against the current as the current speed increases (Johansson et al. 2014, Hvas et al. 2017b). At low current velocities, swimming speeds are therefore voluntary and independent of the ambient environment, while stronger currents may force the fish to swim at speeds dictated by the environment (Johansson et al. 2014, Hvas et al. 2017b). Preventing fish from swimming at their preferred cruising speed for prolonged periods is a legitimate welfare concern (Hvas et al. 2017b), and the excess energy expenditure required for faster swimming will also, to some extent, affect production performance (Solstorm et al. 2015).

In more extreme current conditions, the maximum swimming capacity of farmed fish may be exceeded, resulting in physiological fatigue, severe stress, injury and even death as the fish gets stuck on the downstream net pen wall (Oppedal et al. 2011, Remen et al. 2016). Experimental measurement of the critical swimming speed ( $\left.U_{\text {crit }}\right)$ of fish (e.g. Remen et al. 2016, Hvas \& Oppedal 2017) is a standardized method to assess the upper current velocities farmed fish are able to handle on acute timescales. $U_{\text {crit }}$ is a measure of prolonged swimming capacity originally defined by Brett (1964). Since swimming at $U_{\text {crit }}$ or higher speeds leads to fatigue, farmed fish should never be exposed to current conditions of such magnitudes in sea cages. Furthermore, $U_{\text {crit }}$ and swimming behaviour are affected by environmental and biological factors such as water temperature, fish size, individual variations and diseases (Brett 1964, Beamish 1978, Remen et al. 2016, Hvas et al. $2017 \mathrm{a}, \mathrm{b})$, which complicate welfare risk assessments at exposed locations. Weak currents may also become problematic, especially when combined with high temperatures, owing to increased risks of hypoxia inside salmon cages, which reduces feed intake and growth (Johansson et al. 2007, Remen et al. 2014, Solstorm et al. 2018).

The primary focus concerning the welfare of Atlantic salmon farmed in exposed environments is on the evaluation of their swimming behaviour and their ability to cope with the prevailing environmen- tal conditions. However, in recent years, there has been a drastic increase in the use of cleaner fish in sea cages for delousing, where the lumpfish Cyclopterus lumpus is the most widely used species (Imsland et al. 2014, Powell et al. 2017). In Norway alone, the use of lumpfish has increased from 15.8 million lumpfish in 2016 to 27 million in 2017 (Fiskeridirektoratet 2018). As a vertebrate species, lumpfish possess the same animal rights as Atlantic salmon according to Norwegian laws (Dyrevelferdsloven 2009), thus the same concern regarding welfare in an exposed setting applies to lumpfish. The $U_{\text {crit }}$ of lumpfish is considerably lower than in Atlantic salmon owing to smaller sizes and a morphology less suited for fast swimming (Hvas et al. 2018). This suggests that lumpfish are more likely to experience poor welfare at sites with rough current conditions.

In accordance with Norwegian law, all planned aquaculture sites must be surveyed to classify the prevailing environmental conditions. All fish farm systems must be certified according to the rules in Standard NS-9415 (NAS 2009) which ensure the structural integrity of the farm and prevent escapes. NS-9415 defines 5 current classes based on speed, ranging from 'little exposure' to 'extreme exposure' (Table 1). This system for classifying locations does not consider fish welfare, a cause for concern when considering the documented swimming capabilities of Atlantic salmon. For example, the middle category of NS-9415, termed 'substantial exposure', corresponds to an interval of current magnitudes similar to the $U_{\text {crit }}$ of Atlantic salmon post-smolts ranging from 80 to $800 \mathrm{~g}$ (Remen et al. 2016, Hvas \& Oppedal 2017).

Since exposed salmon farming is a new concept, thorough environmental descriptions of sites are currently lacking, and their suitability for responsible fish production has not yet been clarified. Hence, the purpose of this study was to characterize current conditions at exposed locations and assess whether fish welfare is at risk by comparing the ambient environment with known swimming capabilities of Atlantic

Table 1. Classification of aquaculture sites in Standard NS9415 (NAS 2009) based on the 10 yr return period of the current velocity $\left(V_{\mathrm{c}}\right)$

\begin{tabular}{|lcl|}
\hline Current class & $V_{\mathrm{c}}\left(\mathrm{m} \mathrm{s}^{-1}\right)$ & Designation \\
\hline A & $0.0-0.3$ & Little exposure \\
B & $0.3-0.5$ & Moderate exposure \\
C & $0.5-1.0$ & Substantial exposure \\
D & $1.0-1.5$ & High exposure \\
E & $>1.5$ & Extreme exposure \\
\hline
\end{tabular}


salmon and lumpfish. To achieve this, a new method was presented and evaluated based on data from site surveys. This method consisted of 2 parts. First, a new scheme for classifying water currents based on known swimming behaviours and capacities of Atlantic salmon was derived as a supplement to NS9415. To identify potential low oxygen events (i.e. when currents are weak) and to determine if the swimming capacities of the fish are exceeded, the number of continuous hours the measured currents occurred within each current class was determined. Secondly, the suitability of specific sites was inspected using current and temperature data and known $U_{\text {crit }}$ limits for Atlantic salmon and lumpfish. The method was applied to data from 5 sites along the Norwegian coast, most of them representative of the present trend of moving Atlantic salmon farms to more exposed locations. For the most exposed site, a characterization of extreme events was also established.

\section{MATERIALS AND METHODS}

\subsection{Data collection and locations}

Ocean current data were collected using acoustic Doppler current profilers (ADCP; Aquadopp $400 \mathrm{kHz}$, Nortek) at 5 selected locations along the Norwegian coast between November 2014 and July 2018. Each ADCP was deployed on a multi-sensor SEAWATCH buoy (Fugro Oceanor) equipped with a conductivity and temperature sensor (Aanderaa 3919A, Aanderaa Data Intruments).

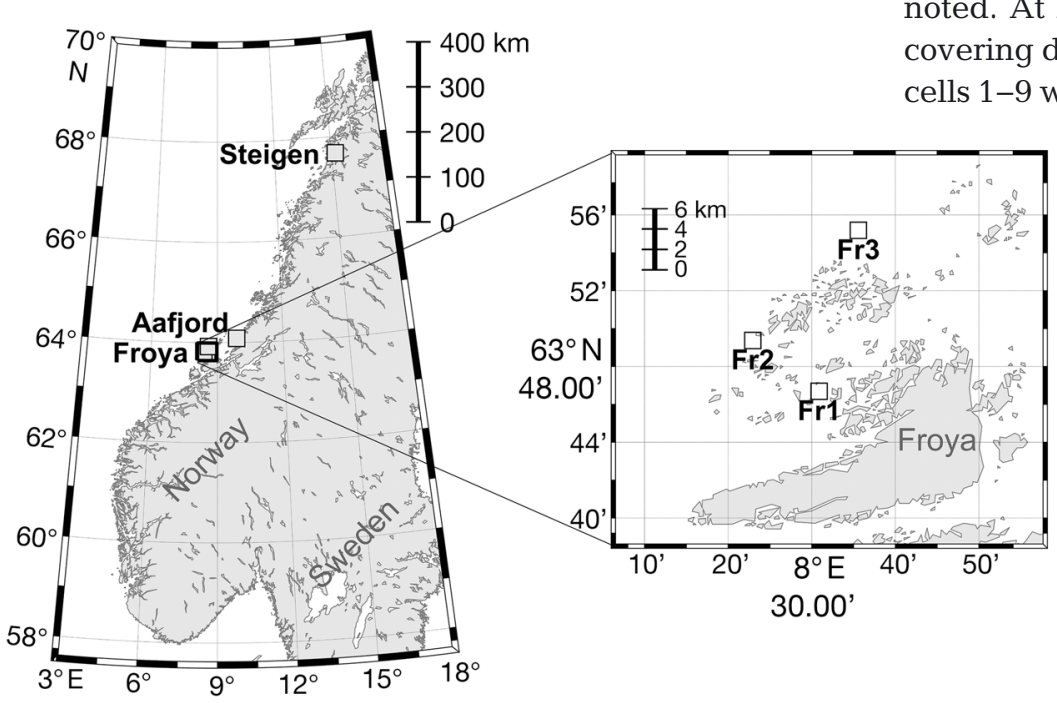

Fig. 1. Locations of the acoustic Doppler current profilers (ADCPs) at Åfjord (Aafj), Steigen (Ste), and the Frøya archipelago (Fr1, Fr2 and Fr3)

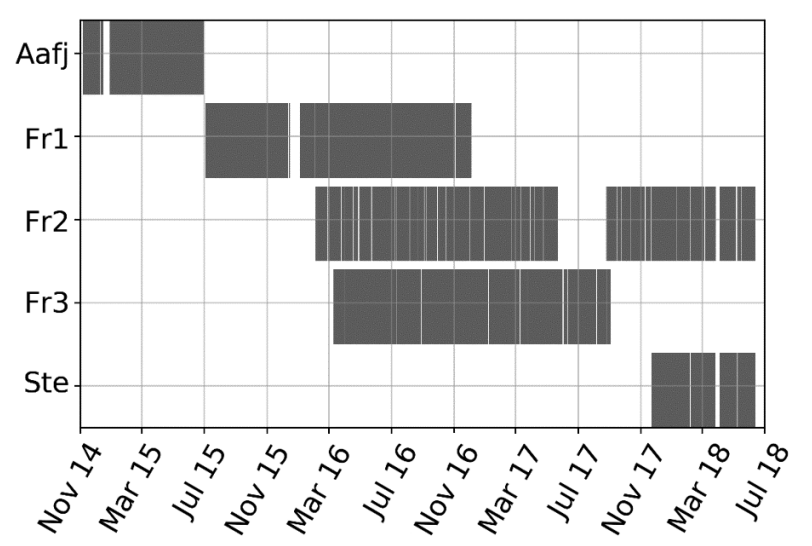

Fig. 2. Deployment and active periods for the ADCPs from 2014 to 2018. From deployment to recovery, the temporal coverage was $94 \%$ at Aafj (with hours sampled, $\mathrm{n}=5332$ ), $96 \%$ at $\operatorname{Fr} 1(\mathrm{n}=11969), 86 \%$ at Fr2 $(\mathrm{n}=17675), 99 \%$ at $\mathrm{Fr} 3$ $(\mathrm{n}=13019)$ and $95 \%$ at Ste $(\mathrm{n}=4612)$. See Fig. 1 for site locations

Three of the ADCPs were located in the Frøya archipelago (Fr1, Fr2 and Fr3), and the other 2 in Åfjord (Aafj) and Steigen (Ste) municipality, respectively (Fig. 1). Fig. 2 shows when the ADCPs were deployed and active at the different locations. The minimum deployment span for each ADCP was $5 \mathrm{mo}$, and all units were active during at least 1 winter season from November to February. The velocity profile measured by the ADCP is divided into uniform segments called depth cells. The size of the depth cells varied between locations. At 2 of the locations, Aafj and Fr1, the cell size was set to $4 \mathrm{~m}$, while the remaining ADCPs operated with a cell size of $3 \mathrm{~m}$. Because of varying depths at the different locations, only the data from the first $30 \mathrm{~m}$ in each dataset were studied unless otherwise noted. At Aafj and Fr1, this corresponds to cells 1-7 covering depths 3.5-31.5 m, while at Fr2, Fr3 and Ste, cells 1-9 were applied, covering $2.5-29.5 \mathrm{~m}$.

All ADCPs were installed facing downward and configured to perform measurements over the last $10 \mathrm{~min}$ of each hour and produce averaged values of these data series. This sampling procedure is sufficient to resolve the tidal fluctuations, as the semidiurnal tidal constituents dominate along the Norwegian coastline (Sætre 2007), as well as strong currents in the upper water column due to interaction between tides and strong winds. Averaging over 10 min will smooth out turbulent motion and measurement error, but may also to some degree remove information on the exact size of current 
peaks. This is not considered an issue, as it is the generalized characteristics of the sites that are of interest here rather than short-term fluctuations.

\subsection{Initial processing of data}

Unrealistic data points were removed in accordance with recommended procedures for quality control of buoy-mounted ADCPs (SeaDataNet 2010). For each dataset, the mean, SD and maximum and minimum current speed were calculated. The significant maximum and minimum, defined as the mean of the 1/3 largest and 1/3 smallest current speeds, were also determined.

The 10 yr return current describes the current speed which is exceeded on average once every $10 \mathrm{yr}$. This value is used officially for site classification in Norway, was calculated at depths of 7 and $9.5 \mathrm{~m}$, depending on location. The current was determined following the method described in Standard NS-9415 (NAS 2009) for 1 mo site surveys using the maximum current speed measured during the entire deployment.

\subsection{Defining current classes}

A proposed classification scheme for ambient current conditions based on previous studies of swimming behaviours and $U_{\text {crit }}$ of Atlantic salmon Salmo salar is summarized in our Table 2 (Gansel et al. 2014, Johansson et al. 2014, Remen et al. 2016, Hvas et al. 2017a,b). The classes representing the weakest currents, 'very weak' (0-10 $\left.\mathrm{cm} \mathrm{s}^{-1}\right)$ and 'weak' (10$20 \mathrm{~cm} \mathrm{~s}^{-1}$ ), define the interval of current speeds where large Atlantic salmon are known to swim freely and unaffected. The 'very weak' class was included to isolate events of low oxygen levels that may occur in

Table 2. Definition of current classes based on established limits related to the onset of behavioural changes and critical swimming speed $\left(U_{\text {crit }}\right)$ of Atlantic salmon

\begin{tabular}{|c|c|c|}
\hline \multicolumn{2}{|c|}{ Current } & \multirow[t]{2}{*}{ Swimming behaviour } \\
\hline Speed $\left(\mathrm{cm} \mathrm{s}^{-1}\right)$ & Class & \\
\hline $0-10$ & Very weak & Swimming freely \\
\hline $10-20$ & Weak & Swimming freely \\
\hline $20-40$ & Moderate & $\begin{array}{l}\text { Circular pattern is disrupted; } \\
\text { some fish standing on current }\end{array}$ \\
\hline $40-50$ & Substantial & Most fish standing on current \\
\hline $50-60$ & Strong & All fish standing on current \\
\hline$>60$ & Very strong & Exceeds $U_{\text {crit }}$ \\
\hline
\end{tabular}

stagnant water. The third class, 'moderate' $(20-40 \mathrm{~cm}$ $\mathrm{s}^{-1}$ ), covers the speeds where large Atlantic salmon start showing signs of breaking up their circular swimming pattern and some of the fish begin to stand on the current. Previous studies have observed that in sea cages, all fish stand on the current when current speeds exceeded roughly $45 \mathrm{~cm} \mathrm{~s}^{-1}$ (Johansson et al. 2014, Hvas et al. 2017b). The 'substantial' class $\left(40-50 \mathrm{~cm} \mathrm{~s}^{-1}\right)$ therefore covers the transition from a non-homogeneous swimming pattern to a polarized school where most fish stand on current, while the 'strong' (50-60 $\mathrm{cm} \mathrm{s}^{-1}$ ) class contains only the latter behaviour. Finally, the 'very strong' class was based on conservative estimates of the $U_{\text {crit }}$ where low temperatures and smaller fish sizes are considered and reflects current conditions where fish are at risk of reaching physiological fatigue. This was done using the $U_{\text {crit }}$ value of $80.6 \mathrm{~cm} \mathrm{~s}^{-1}$ for small post-smolts of $80 \mathrm{~g}$ swimming in groups at $14^{\circ} \mathrm{C}$ (Remen et al. 2016) and assuming a $20 \%$ decrease in swimming performance when reducing the temperature to $3^{\circ} \mathrm{C}$ (Hvas et al. 2017a), resulting in a $U_{\text {crit }}$ value of $64.5 \mathrm{~cm} \mathrm{~s}^{-1}$. To also account for individual differences, the 'very strong' limit was set to $60 \mathrm{~cm} \mathrm{~s}^{-1}$.

\subsection{Identification and duration of classes}

Current conditions theoretically experienced by the fish were studied by classifying the mean current speeds at each location for each time sample and depth layer using the defined classes in Table 2. The distribution of classes within each depth layer over the entire deployment was determined by sorting all mean values collected for each individual cell.

To assess the impact of current speed on swimming capacity of Atlantic salmon, the number of successive hours the water column stayed within a given current class was determined. As it remains uncertain whether fish will actively seek to avoid depth layers with adverse currents (Oppedal et al. 2011), 2 different criteria were used to define the class of the water column, homogeneous and non-homogeneous. The homogeneous criterion requires that all depth layers in the water column share a single class. If 1 or more depth layers differ from the others, the sample is considered mixed. When using the homogeneous criterion, 2 samples are considered consecutive only if all depth layers in both samples have the same class. The non-homogeneous criterion is less stringent in only requiring 1 depth layer in the water column to be of a given class. This means that a single time sample will be classified according to all classes 
present in the water column. Two samples are then considered consecutive if at least 1 cell in each sample shares classification.

The most relevant depth layers for assessing fish welfare are those containing the largest biomass. Due to observed preferred swimming depth and diurnal swimming pattern (Oppedal et al. 2011), it was assumed that the top $20 \mathrm{~m}$ of the water column would contain most of the biomass. Hence, only the top $20 \mathrm{~m}$ were included when determining the duration of events where the water column was defined within specific current classes. These were cells 2-5 at Fr2, Fr3 and Ste and cells 2-4 at Fr1 and Aafj, corresponding to depth intervals of 5.5-17.5 and 7.5$19.5 \mathrm{~m}$, respectively. The first depth cell at each site was excluded, as buoy-mounted ADCPs can experience a bias in near-surface observations (Mayer et al. 2007).

In addition, the duration of periods where current speeds continuously exceeded $30 \mathrm{~cm} \mathrm{~s}^{-1}$ were extracted, since it has been shown that chronic exposure above this magnitude may compromise growth performance in post-smolts (Solstorm et al. 2015).

\subsection{Evaluation of current data using $U_{\text {crit }}$ and water temperature}

To account for thermal effects on $U_{\text {crit }}$, the measured horizontal current speeds were normalized using a temperature-dependent function, $\hat{U}_{\text {crit }}(T)$. Normalized current speeds $(\tilde{U})>1$ then represent current speeds higher than measured $U_{\text {crit }}$ values at the given temperature.

$\hat{U}_{\text {crit }}(T)$ was created by polynomial regression, fitting a $2^{\text {nd }}$-degree polynomial function to data for Atlantic salmon of $\sim 450 \mathrm{~g}$ acclimated to 5 different temperatures (Hvas et al. 2017a) (Fig. 3). Furthermore, this function was scaled down to represent a smaller post-smolt of $80 \mathrm{~g}$ with a scaling factor $k$, using the measured maximum $U_{\text {crit }}=80.6 \mathrm{~cm} \mathrm{~s}^{-1}$ for fish of that size at $14^{\circ} \mathrm{C}$ (Remen et al. 2016):

$$
k=0.806(\mathrm{~m} / \mathrm{s}) / \hat{U}_{\text {crit }}\left(14^{\circ} \mathrm{C}\right)
$$

A scaling factor was also created for adult salmon of $1750 \mathrm{~g}$ using data from Remen et al. (2016), and the $\hat{U}_{\text {crit }}(T)$ for this group is also presented in Fig. 3.

A similar approach was used for lumpfish Cyclopterus lumpus of $\sim 300 \mathrm{~g}$, acclimated to different temperatures (Hvas et al. 2018) using a $2^{\text {nd }}$-degree polynomial (Fig. 3). The polynomial function was also scaled down to represent lumpfish of $\sim 75 \mathrm{~g}$ (Hvas et al. 2018) using a scaling factor with $U_{\text {crit }}=26.9 \mathrm{~cm} \mathrm{~s}^{-1}$ at $9^{\circ} \mathrm{C}$. Due to the small difference in $\hat{U}_{\text {crit }}(T)$, the polynomial function for larger lumpfish was applied when evaluating the current data. Second-degree polynomials were considered adequate for both salmon and lumpfish as they accounted for over $95 \%$ of the variability in the data for both species $\left(\mathrm{r}^{2}=0.98\right.$ for salmon, $\mathrm{r}^{2}=1.0$ for lumpfish).

Eq. (2) expresses the normalized horizontal current speed $\tilde{U}_{i}^{t}$, where $U_{i}^{t}$ is the current speed observed at time $t$ in cell $i, k$ is the scale parameter, $\hat{U}_{\text {crit }}$ is the temperature-dependent function, and $T^{t}$ the measured temperature at time $t$.

$$
\tilde{U}_{i}^{t}=U_{i}^{t} /\left[\hat{U}_{\text {crit }}\left(T^{t}\right) \cdot k\right]
$$

Temperature measurements were gathered at $1 \mathrm{~m}$ depth and assumed constant throughout the water column, which is an oversimplification that may have an impact on the results. Specifically, when inspecting temperature variations within sea cages in surface waters, temperature profiles will typically correlate positively with depth during winter and negatively with depth during summer (Johansson et al. 2006, Oppedal et al. 2011). This means that using temperature measured at $1 \mathrm{~m}$ depth will be a conservative approach when determining $\hat{U}_{\text {crit }}$ during winter, while too high temperatures will be applied for $\hat{U}_{\text {crit }}$ during summer.

For all locations, linear interpolation was applied to fill in missing temperature values. The buoy at Fr3 encountered technical problems and ceased logging temperature $1 \mathrm{mo}$ after deployment. Temperature measurements from Fr2 nearby were used to normal-

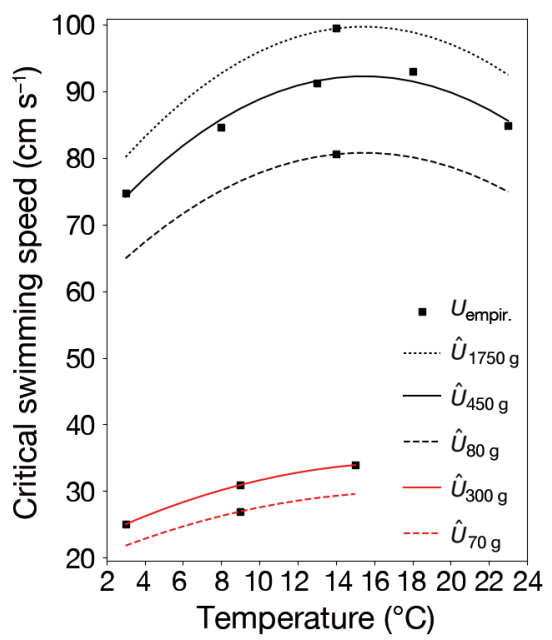

Fig. 3. Temperature-dependent critical swimming speed $\left(\hat{U}_{\text {crit }}\right)$ for Atlantic salmon (black lines) and lumpfish (red lines) of different sizes. The empirical critical swimming speed data $\left(U_{\text {empir. }}\right)$ for Atlantic salmon are from Hvas et al. (2017a) and Remen et al. (2016), and for lumpfish from Hvas et al. (2018) 
ize the current at Fr3, and linear interpolation was carried out when Fr2 was not operative in June and July 2017. This is unlikely to have a notable impact on the results, since the sea temperature changes slowly during the summer, and because the strongest currents occurred during the winter months.

\subsection{Duration and frequency of extreme events}

For the most exposed location, a study was done to determine the duration and frequency of events with current speeds in the 'very strong' class (i.e. exceeding $60 \mathrm{~cm} \mathrm{~s}^{-1}$ ) and the number of successive events exceeding the limit. The non-homogeneous criterion for the water column was applied as the homogeneous criterion was deemed too strict when identifying extreme events.

Ocean currents along the Norwegian coast are influenced by several factors, such as tides, freshwater runoff, Atlantic water inflow, bottom topography, wind and weather conditions (Sæetre 2007). For the tides, the principal lunar and solar semidiurnal tidal constituents are dominant, with periods of 12.42 and $12 \mathrm{~h}$, respectively (Sæetre 2007). Strong currents can occur with both falling and rising tides. From the perspective of the fish, this means that extreme current speed events may arise twice in a $12 \mathrm{~h}$ period. Hence, the number of successive events where the speed was classified as 'very strong' and where there were $>5$ and $<13 \mathrm{~h}$ between events were identified.

\section{RESULTS}

\subsection{Overview and classification of locations}

The current speeds observed at each site are summarized in Table 3. The highest current speed measured was $112.5 \mathrm{~cm} \mathrm{~s}^{-1}$ at Fr2, while Ste had the calmest conditions overall with a maximum current speed of $36.0 \mathrm{~cm} \mathrm{~s}^{-1}$. The classification for each location using Standard NS-9415 shows the same trend, with Fr2 categorized as 'extreme exposure' and Ste as 'substantial exposure'. Aafj, Fr1 and Fr3 were all classified as having 'high exposure'.

\subsection{Distribution and duration of current classes}

The distribution of the different current classes for selected depths is shown in Fig. 4. Observations from Ste and Aafj were predominantly within the 'weak' and 'very weak' classes, with nearly 99\% of all current speeds measured at Ste and $93 \%$ at Aafj in 1 of these 2 classes. All sites in Frøya had a higher percentage of currents in the stronger classes. The data series from Fr2 and Fr3 contained several incidents of currents in the 'very strong' class, while Aafj only had a single occurrence. The recorded 'very strong' currents cover $0.31 \%$ and $0.03 \%$ of the entire deployment time at Fr2 and Fr3, respectively.

The continuous duration of events within each class using the homogeneous and non-homogeneous criterion for the water column are shown as boxplots in Figs. 5 \& 6, respectively. Non-homogeneous water columns were experienced close to twice as often as homogeneous water columns at all locations. Independent of criteria used to inspect the depth layers, Aafj and Ste had the longest durations of 'very weak' currents, and Fr2 had the longest duration of 'very strong' currents. The total number of hours with current speeds over $30 \mathrm{~cm} \mathrm{~s}^{-1}$ based on both the homogeneous and non-homogeneous water column criterion is presented in Fig. 7. The longest durations were 33 and $32 \mathrm{~h}$ at Fr3 and Fr2, respectively, when applying the non-homogeneous water column.

Table 3. Descriptive statistics for all locations displaying mean, maximum, SD, and significant (see Section 2.2) maximum and minimum current speeds. The $10 \mathrm{yr}$ return period calculated in accordance with Standard NS-9415 (NAS 2009 ) and the corresponding current classification are also listed. See Fig. 1 for site locations

\begin{tabular}{|c|c|c|c|c|c|c|c|c|c|}
\hline \multirow[t]{2}{*}{ Site } & \multicolumn{8}{|c|}{ Current speed $\left(\mathrm{cm} \mathrm{s}^{-1}\right)$} & \multirow[t]{2}{*}{ NS-9415 class. } \\
\hline & Mean & Median & Mode & Max. & $\mathrm{SD}$ & Signif. max. & Signif. min. & 10 yr return & \\
\hline Aafj & 8.8 & 7 & 3.5 & 62.1 & 6.9 & 16 & 3.5 & 102.5 & $\mathrm{D}$ \\
\hline Fr1 & 12.6 & 11.7 & 7 & 57.4 & 8.1 & 21.6 & 5.2 & 104.4 & $\mathrm{D}$ \\
\hline Fr2 & 17.6 & 15.2 & 9.4 & 112.5 & 11.8 & 30.5 & 6.9 & 176 & $\mathrm{E}$ \\
\hline Fr3 & 13.9 & 12.9 & 5.9 & 71.5 & 8.2 & 22.2 & 6.4 & 110.2 & $\mathrm{D}$ \\
\hline Ste & 7.2 & 6.2 & 3.2 & 36 & 4.6 & 11.3 & 3.8 & 56.6 & C \\
\hline
\end{tabular}



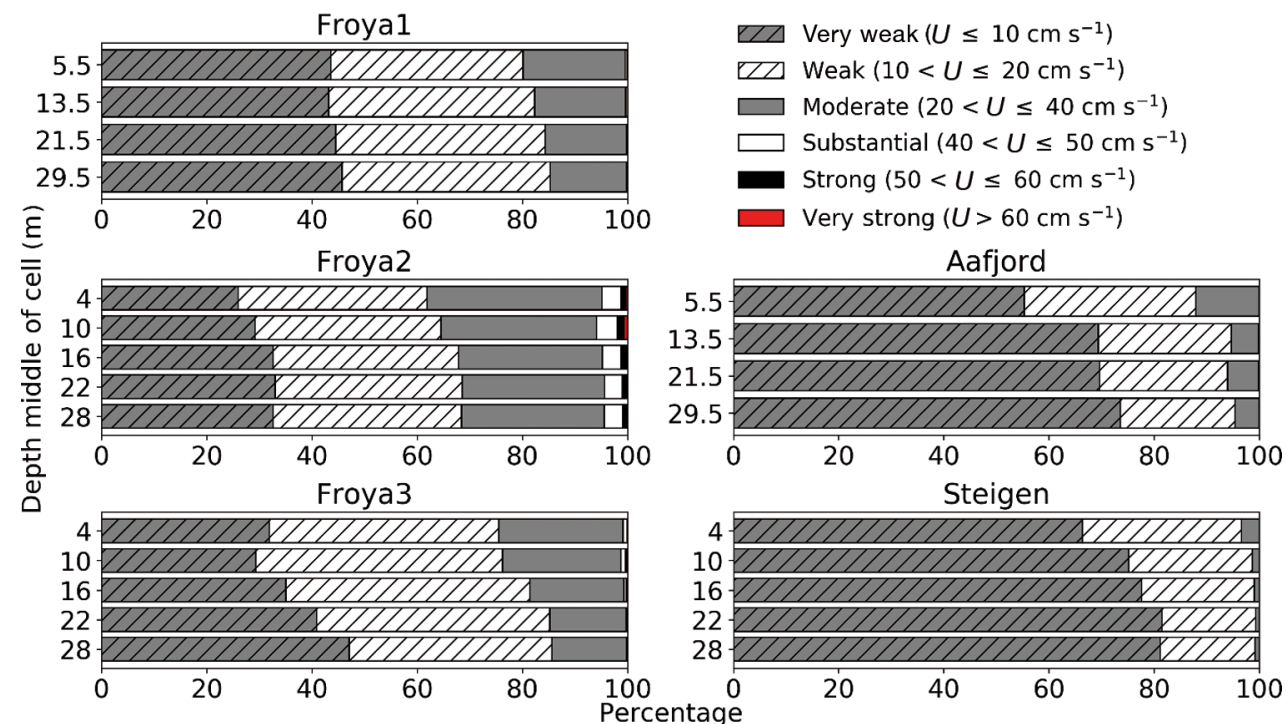

Fig. 4. Total distribution of current classes over the entire duration of deployment for selected depths at each location. $U$ : current speed. See Fig. 1 for site locations

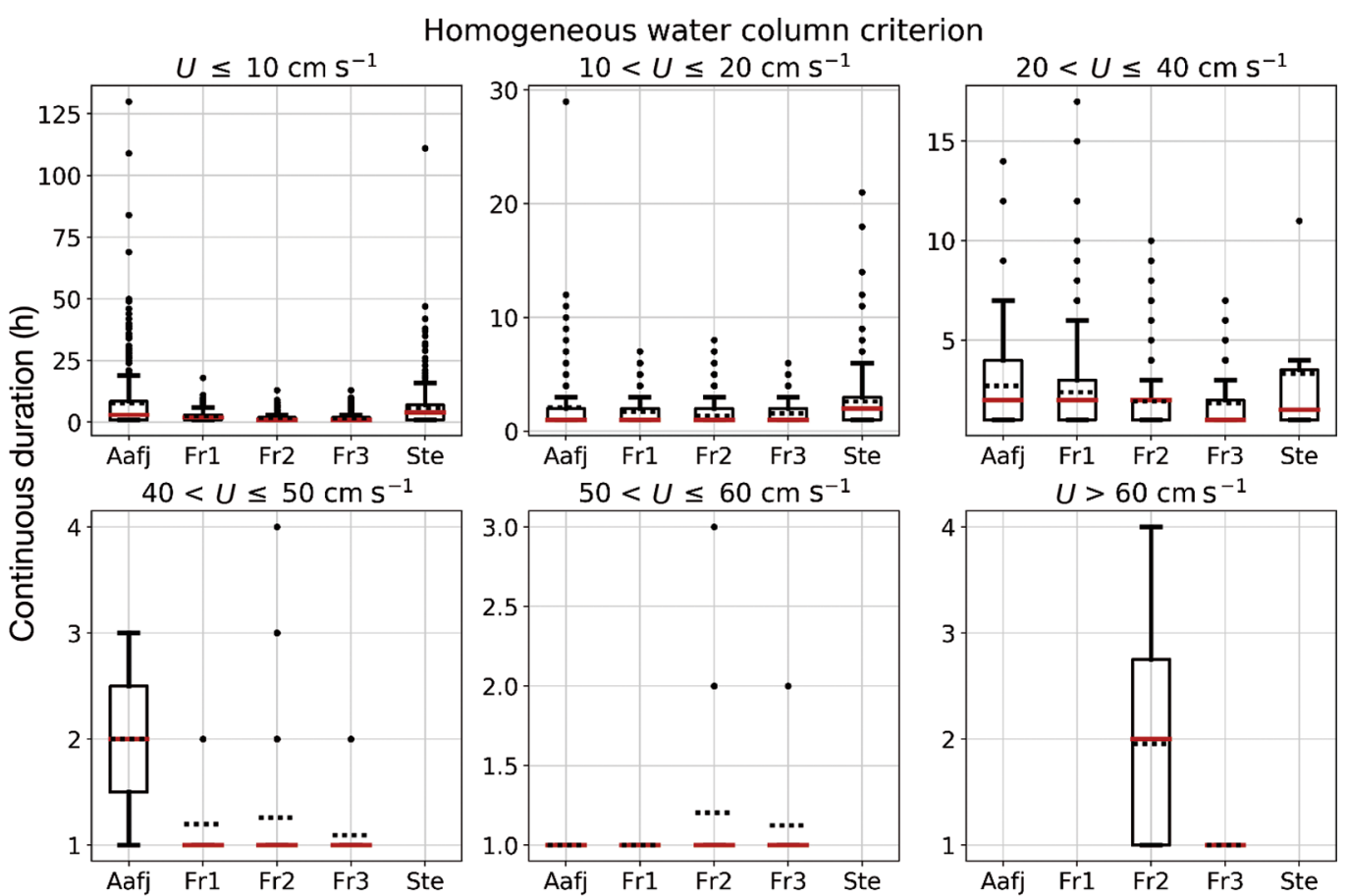

Fig. 5. Number of consecutive hours in each current class using the homogeneous criterion for the water column. Red line: median; horizontal dotted line: mean. Lower whisker extends to first quartile (Q1) minus 1.5 times the interquartile range (IQR). Upper whisker extends to the third quartile (Q3) plus 1.5 × IQR. Data outside of the whiskers are events that exceed Q3 $+1.5 \times$ IQR. These are represented as dots and are considered valid data points. Dots may overlap; hence dots do not necessarily represent a single occurrence. Note the different $y$-axes. $U$ : current speed. See Fig. 1 for site locations

\subsection{Evaluating current data using $U_{\text {crit }}$ and water temperature}

Fig. 8 shows the number of consecutive hours where the currents were within given ranges of $U_{\text {crit }}$ for Atlantic salmon Salmo salar using both the homogeneous and non-homogeneous criterion. Only Fr2 exceeded the $U_{\text {crit }}$ of Atlantic salmon, independent of which criterion was used, for up to $4 \mathrm{~h}$ at a time. The results for lumpfish Cyclopterus lumpus are presented in Fig. 9 and show that $U_{\text {crit }}$ was exceeded at all sites when using the non-homogeneous criterion, and at all sites except Ste when using the homogeneous criterion. These conditions could persist for up to $33 \mathrm{~h}$. 


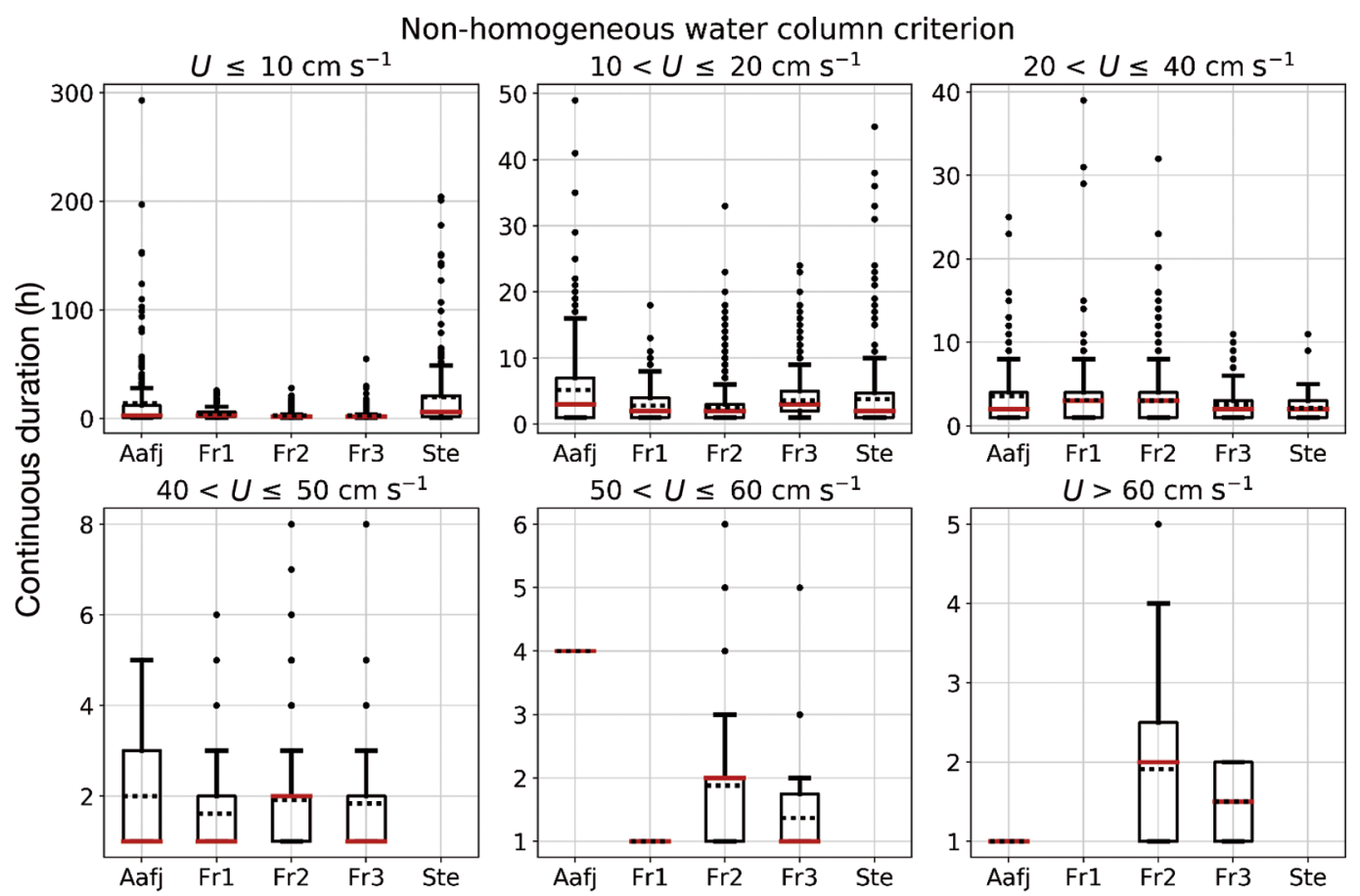

Fig. 6. Number of consecutive hours in each current class using the non-homogeneous criterion for the water column. Other details are the same as for Fig. 5

\subsection{Extreme events at Fr2}

Site Fr2 was selected for the study of extreme events, as it had the most frequent occurrence of current measurements above $60 \mathrm{~cm} \mathrm{~s}^{-1}$. Dates containing more than 3 consecutive tidal cycles are presented in Table 4, and the total hours of each event was found as the time span from the first to the last measured current measurement classified as 'very strong'. The longest duration observed was $51 \mathrm{~h}$ in January 2018, while the maximum recorded current speed and largest mean value were 112.5 and $42.3 \mathrm{~cm} \mathrm{~s}^{-1}$, respectively.

\section{DISCUSSION}

\subsection{Current class definitions based on fish behaviour}

The classification obtained by using Standard NS9415 gives little insight into the actual conditions experienced by the fish, and its usefulness as a descriptive tool should be questioned. For instance, the NS-9415 classification of both Aafj and Fr3 as 'high exposure' sites does not reflect the fact that Aafj, unlike Fr3, has long periods of low currents. The method presented in the present study attempts to resolve this issue by employing observed limits related to behavioural changes and swimming capacities when evaluating the current data. However, certain aspects of the classification should be considered when interpreting the results.

$U_{\text {crit }}$ values are determined in swim tunnels, where fish are exposed to a continuous flow of constant velocity in systematic increments, a situation rarely experienced in nature (Plaut 2001). In addition, current speeds inside and outside of a sea cage are not necessarily alike, as a significant reduction of speed may occur over the net of sea cages and over the entire farm installation (Klebert et al. 2013,

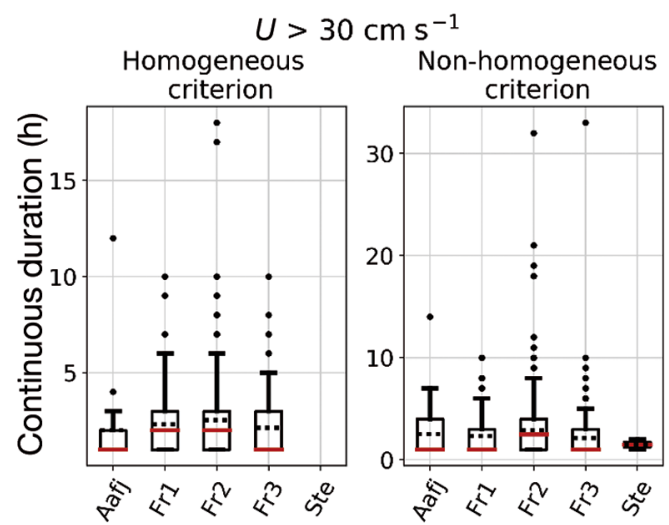

Fig. 7. Number of consecutive hours with current speeds exceeding $30 \mathrm{~cm} \mathrm{~s}^{-1}$ based on both the homogeneous and non-homogeneous water column criterion. Other details are the same as for Fig. 5 


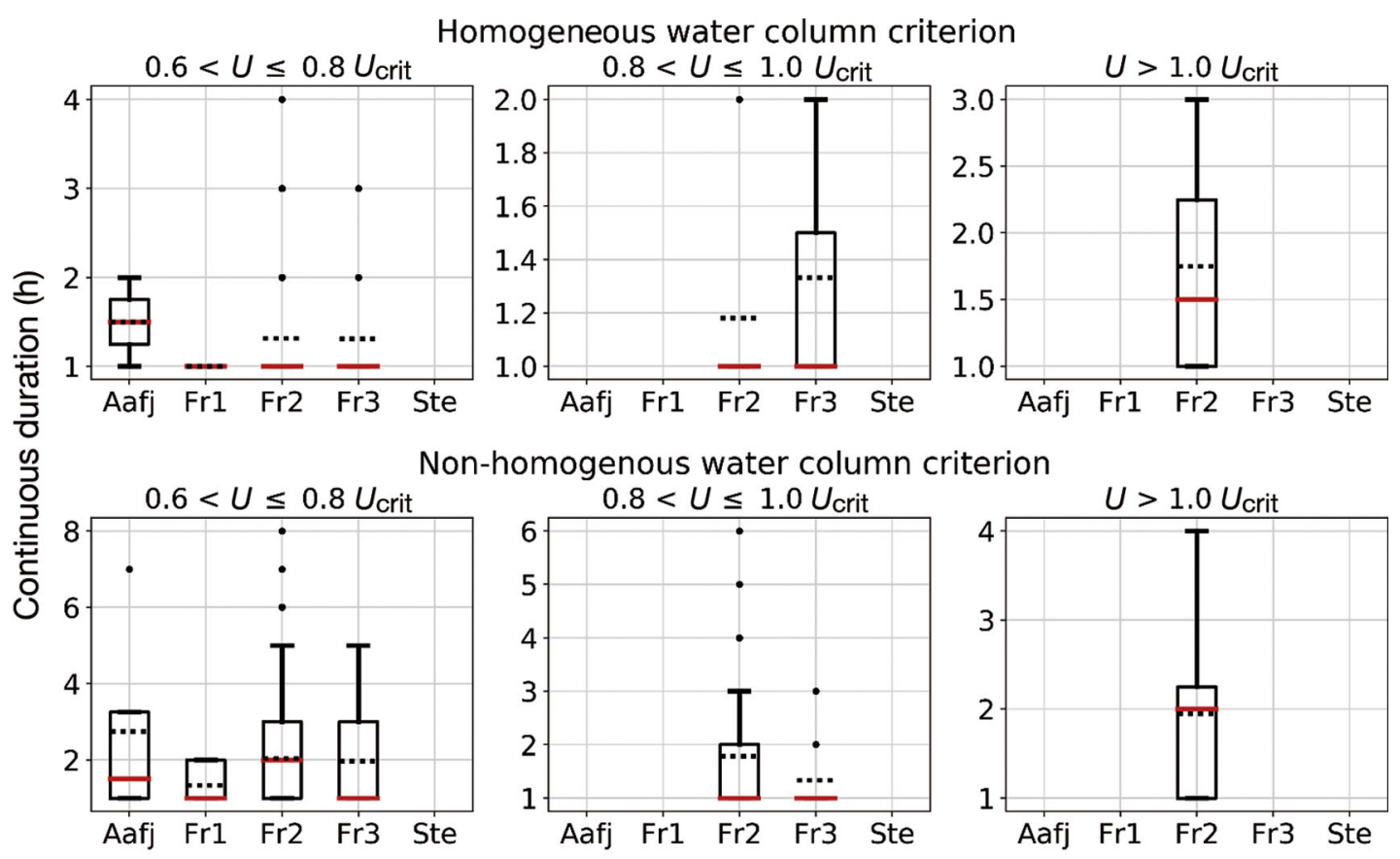

Fig. 8. Number of consecutive hours where the currents were within given ranges of the critical swimming speed ( $\left.U_{\text {crit }}\right)$ for Atlantic salmon Salmo salar using both the homogeneous and non-homogeneous criterion. Other details are the same as for Fig. 5

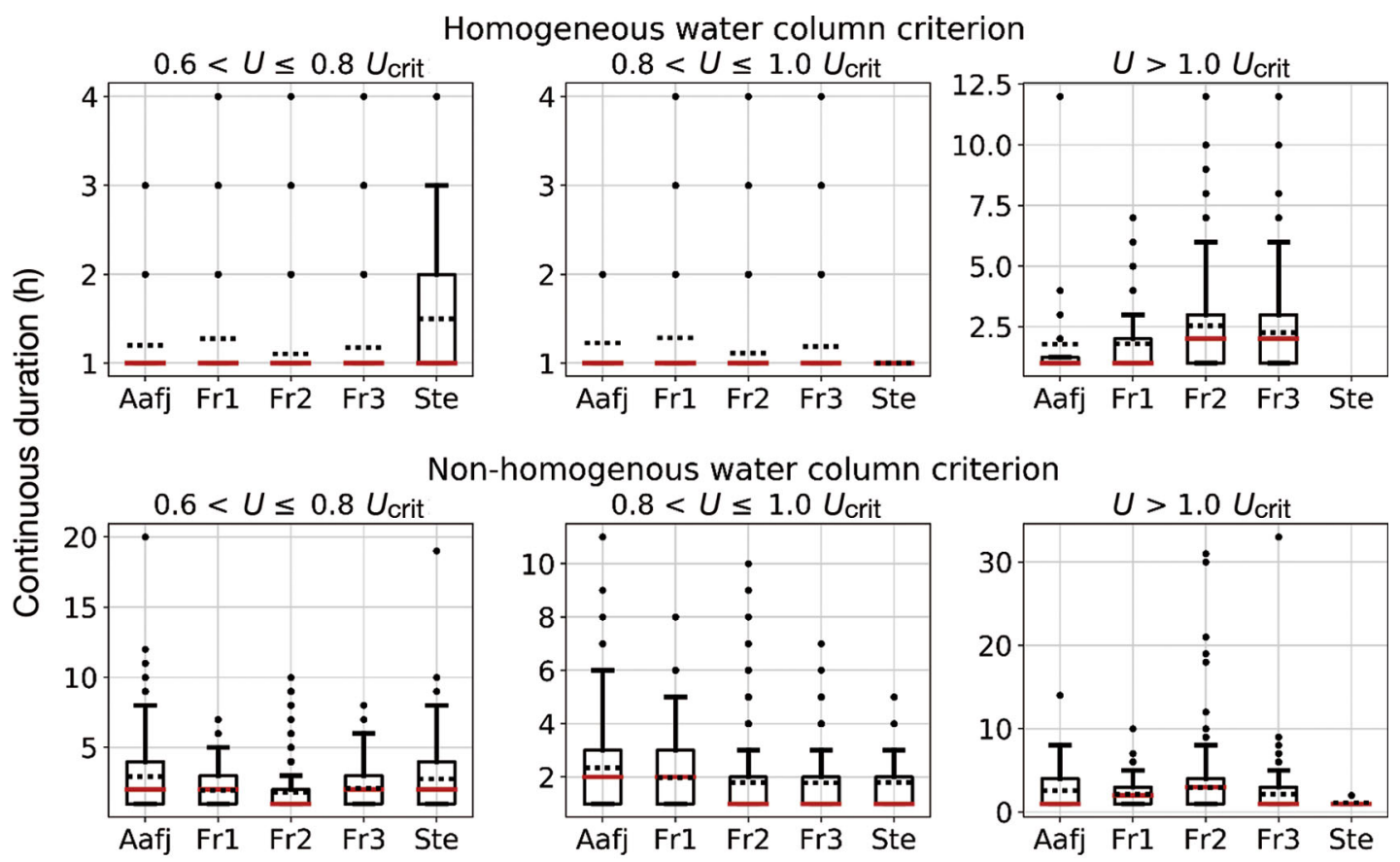

Fig. 9. Number of consecutive hours where the currents were within given ranges of the critical swimming speed $\left(U_{\text {crit }}\right)$ for lumpfish Cyclopterus lumpus using both the homogeneous and non-homogeneous criterion. Other details are the same as for Fig. 5

Winthereig-Rasmussen et al. 2015). Several factors influence this reduction in speed, such as net dimensions, biofouling, presence of fish and potentially the deformation of the sea cages (Klebert et al. 2013, Gansel et al. 2014, Winthereig-Rasmussen et al.
2016). Klebert et al. (2015) report a reduction of $21.5 \%$ in current speed from a reference point outside to inside a fish pen, which compares well with the reduction of $20 \%$ found applying the empirical method of Løland (1991). Higher reductions have 
Table 4. Statistics for periods containing consecutive cycles with currents in the 'very strong' class. Total hours: duration from the first recorded to the last recorded 'very strong' current that has $>5$ and $<13 \mathrm{~h}$ between them

\begin{tabular}{|lccccc|}
\hline \multirow{2}{*}{$\begin{array}{l}\text { Year/ } \\
\text { date }\end{array}$} & $\begin{array}{c}\text { No. of } \\
\text { tidal cycles }\end{array}$ & $\begin{array}{c}\text { Total } \\
\text { time }(\mathrm{h})\end{array}$ & \multicolumn{4}{c|}{$\begin{array}{c}\text { Current } \\
\text { Max. }\end{array}$} & Mean $\left(\mathrm{cm} \mathrm{s}^{-1}\right)$ & Min. \\
\hline $\mathbf{2 0 1 7}$ & & & & & \\
3-4 Nov & 3 & 18 & 70.3 & 35.5 & 1.2 \\
3-4 Dec & 3 & 26 & 77.3 & 33.3 & 7.0 \\
2018 & & & & & \\
3-5 Jan & 5 & 51 & 96.1 & 33.6 & 1.2 \\
1-3 Feb & 4 & 39 & 80.9 & 29.6 & 0.0 \\
24-25 Apr & 3 & 27 & 72.7 & 42.3 & 8.2 \\
30 Apr-1 May 3 & 27 & 112.5 & 40.0 & 0.0 \\
\hline
\end{tabular}

however been reported when the sensors are located such that fish may influence the measurements (Johansson et al. 2014).

The measurements used in this study were collected in open water outside and apart from farm structures, and it is reasonable to assume that the current speed could be reduced by $20 \%$ within a sea cage. This has implications for the defined current classes, and it can be argued that the 'very strong' class limit of $60 \mathrm{~cm} \mathrm{~s}^{-1}$ is somewhat low and should be increased to account for the reduction over the net. In addition, $U_{\text {crit }}$ of larger Atlantic salmon Salmo salar have been reported as high as $125 \mathrm{~cm} \mathrm{~s}^{-1}$ (Hvas et al. 2017b), while the 'very strong' class is based on results for small post-smolts swimming at $3^{\circ} \mathrm{C}$, which represent the conditions of poorest swimming capacity. Furthermore, the presence of diseases or parasites may lead to a further reduction of $U_{\text {crit }}$ (Hvas et al. $2017 \mathrm{c}$ ). Ideally, the 'very strong' class should reflect the specific species in question, body size and ambient temperature and account for inherent variation in swimming capacities in the population so that weaker individuals are protected. The 'very strong' class could thus be used to give an indication whether current speed should be considered more carefully at a prospective site or not.

\subsection{Choice of criteria and implications for results}

The duration of the 'very weak' and 'weak' classes vary with choice of criteria for the water column. For instance, the maximum continuous duration of 'very weak' currents were 130 and $293 \mathrm{~h}$ at Aafj, and 111 and $204 \mathrm{~h}$ at Ste, using the homogeneous and nonhomogeneous criterion, respectively. This variation between choice of criterion was higher than that observed for the 'strong' and 'very strong' classes.
For example, the maximum duration of the 'very strong' class at Fr2 only increased by $1 \mathrm{~h}$ with the non-homogeneous criterion.

Current speed generally tends to decrease with depth in the upper water column, a trend seen in Fig. 4. If the non-homogeneous criterion is applied, the possible variation in current speed with depth gives fish the theoretical option to avoid strong currents by changing their depth. Atlantic salmon are rarely distributed evenly inside a sea cage, and often display circadian rhythms with respect to swimming depth, where they descend and swim relatively deep during the day and closer to the surface at night (Johansson et al. 2006, 2007, Oppedal et al. 2011). However, there are currently no studies that have shown that salmon actively avoid depth layers with high current speeds (Johansson et al. 2007, Oppedal et al. 2011), suggesting that the non-homogeneous criterion should be preferred when evaluating the effect of strong currents on fish welfare.

When investigating the probability of low oxygen levels because of slow currents, the homogeneous water column criterion is more suitable, as low oxygen levels are expected only when the current speeds are low in all relevant layers. Earlier work has indicated that salmon may avoid areas of slightly lowered oxygen levels (Oldham et al. 2017) and extreme hypoxia (Dempster et al. 2016, Stehfest et al. 2017), but this may be overruled by their preferred temperature at the depth of hypoxia (Stien et al. 2012). The homogeneous criterion is therefore more suitable when considering the risk of hypoxia in weak currents.

\subsection{Classification and site suitability}

Applying the suggested method to ocean current data from the 5 sites can reveal crucial information about the environment as experienced by the fish. The long durations of the 'very weak' currents recorded at Aafj and Ste could have implications for hypoxia events. Long durations of 'very weak' currents, or at high frequencies, especially during late summer and autumn when temperatures are elevated or stocking densities are high, are associated with environmental hypoxia, which can be detrimental to fish growth and health (Burt et al. 2012, Remen et al. 2013, 2014).

Current speeds over $30 \mathrm{~cm} \mathrm{~s}^{-1}$ were measured at all locations, with durations up to $33 \mathrm{~h}$ with the nonhomogeneous criterion. Post-smolts kept at currents around $30 \mathrm{~cm} \mathrm{~s}^{-1}$ for $6 \mathrm{wk}$ display reduced growth 
(Solstorm et al. 2015). Slack current conditions of $4 \mathrm{~cm} \mathrm{~s}^{-1}$, on the other hand, resulted in higher lipid content in the muscle compared to post-smolt kept at moderate currents of $18 \mathrm{~cm} \mathrm{~s}^{-1}$ (Solstorm et al. 2015). Nevertheless, this may not be relevant for salmon in commercial cages where salmon frequently display daytime schooling with swimming speeds of $>0.5$ fish length $\mathrm{s}^{-1}$ (Oppedal et al. 2011, Hansen et al. 2017).

Atlantic salmon have been observed to sustain $80 \%$ of $U_{\text {crit }}$ for at least $4 \mathrm{~h}$ (Hvas \& Oppedal 2017). Fr2 was the only location to exceed this, with current speeds between 80 and $100 \%$ of $U_{\text {crit }}$ persisting up to 6 consecutive hours when employing the nonhomogeneous criterion. This location was also the only one to exceed the $U_{\text {crit }}$ of small post-smolts and had up to 5 consecutive events with current speeds in the 'very high' class (Table 4). Depending on fish size and the reduction of current through the cage walls, the maximum current of $92 \mathrm{~cm} \mathrm{~s}^{-1}$, measured during this extreme period in January 2018, could have a detrimental effect on the fish. The minimum velocity during this period was $1 \mathrm{~cm} \mathrm{~s}^{-1}$ (Table 4), meaning that restitution between the 'very strong' current speeds could be possible with a maximum period between 2 extreme events set to $13 \mathrm{~h}$. Should the fish withstand the strong currents during the peaks, this may provide sufficient time for recovery. However, it is uncertain how the cumulative impact of 5 cycles of strong currents will affect the welfare of Atlantic salmon, and the welfare of the much smaller lumpfish Cyclopterus lumpus.

Unlike salmon, lumpfish has the option to adhere to surfaces such as rocks and seaweed by use of a ventral suction disc and can thereby withstand currents much higher than their $U_{\text {crit }}$ (Hvas et al. 2018). For instance, lumpfish can remain attached to a surface for $1 \mathrm{~min}$ when exposed to currents of $110 \mathrm{~cm} \mathrm{~s}^{-1}$ (Hvas et al. 2018). For this reason, exceeding $U_{\text {crit }}$ may not have the same short-term consequences as for salmon. However, lumpfish in swimming tunnels did not adhere to a surface for more than $20 \mathrm{~min}$, independent of current speed (Hvas et al. 2018). The long duration of currents exceeding $U_{\text {crit }}$ at all of the studied locations could therefore be a serious challenge for their wellbeing.

The suitability of the 5 locations for both species can be summarized by saying that all sites except Fr2 could be suitable for post-smolts as small as $80 \mathrm{~g}$, while none of the locations appear suitable for lumpfish as they all exceed their $U_{\text {crit }}$ for as long as $33 \mathrm{~h}$ at a time.

Despite each ADCP having similar configurations, direct comparisons between locations are compli- cated by the different cell sizes, deployment dates and duration of deployment. For instance, Fr2 had the longest deployment time, increasing the probability of recording strong current speeds. Further work should focus on expanding the method presented in this paper to classify existing and prospective farm sites using model data from ocean models such as SINMOD (SINTEF) or Norkyst800 (Havforskningsinstituttet). Combining these classifications with wind-wave exposure classification using the fetch analysis in Lader et al. (2017) would establish a good foundation for defining an exposed location and fish welfare at such a site. The effect of strong waves on fish welfare should also be studied in more detail, such that a greater understanding of welfare at exposed sites can be obtained.

\section{CONCLUSION}

Standard NS-9415 aims to prevent escapes and focuses on assessing the environment with regard to structural loads. However, if fish farmers only commission providers of site surveys to comply with Standard NS-9415, important information about the environment as experienced by the fish is lost. In this study, a new method for classification of aquaculture sites with respect to current conditions and their implications for fish welfare was proposed and applied to 5 different locations along the Norwegian coast.

The steps of the method can be summarized as follows. For a specific site, define the 'very strong' class on the $U_{\text {crit }}$ of the relevant species and classify current data in accordance with the scheme. To evaluate if hypoxia may become an issue, the duration of 'very weak' currents should be inspected with a homogeneous water column criterion. If 'very strong' current speeds are registered, the duration of the strong currents should be inspected with the nonhomogeneous water column criterion. The current speeds should also be evaluated using a temperature-dependent function, $\hat{U}_{\text {crit }}(T)$, for all relevant species, if temperature data is available. Of the 5 sites included in this study, only Fr2 had current speeds that exceeded $U_{\text {crit }}$ of small post-smolt Salmo salar, while all sites surpassed the $U_{\text {crit }}$ of lumpfish Cyclopterus lumpus. The use of lumpfish at these sites may therefore be problematic with regards to their welfare.

The presented method should be adapted and offered as part of the site surveys for fish farmers to assess prospective sites and to plan production and 
stocking of fish. The method is easily adapted to different species if their $U_{\text {crit }}$ is known. By analyzing the prevalence and persistence of different current speed classes and comparing this with known limits of a specific species' $U_{\text {crit, }}$ prospective production sites can be assessed with respect to fish performance and welfare.

Acknowledgements. This study was funded by SINTEF OCEAN and the Research Council of Norway, EXPOSED Aquaculture Research Centre, grant number 237790. We are thankful for access to measurement data provided by SINTEF ACE and the fish farmers participating in EXPOSED.

\section{LITERATURE CITED}

Beamish FWH (1978) Swimming capacity. Fish Physiol 7: 101-187

Bjelland HV, Føre M, Lader P, Kristiansen D and others (2015) Exposed aquaculture in Norway. In: Conf Proc OCEANS 2015. Institute of Electrical and Electronics Engineers (IEEE) and Marine Technology Society (MTS), Washington, DC, p 1-10

Brett JR (1964) The respiratory metabolism and swimming performance of young sockeye salmon. J Fish Res Board Can 21:1183-1226

Burt K, Hamoutene D, Mabrouk G, Lang C and others (2012) Environmental conditions and occurrence of hypoxia within production cages of Atlantic salmon on the south coast of Newfoundland. Aquacult Res 43:607-620

Dempster T, Wright D, Oppedal F (2016) Identifying the nature, extent and duration of critical production periods for Atlantic salmon in Macquarie Harbour, Tasmania, during summer. Fisheries Research and Development Corporation (FRDC) Rep no. 2016-229-DLD. FRDC, Deakin

* Dyrevelferdsloven (2009) Lov om dyrevelferd (LOV-200906-19-97). https://lovdata.no (accessed 7 Nov 2018)

Fiskeridirektoratet (2018) Utsett av rensefisk 1998-2017. https://www.fiskeridir.no (accessed 10 Sep 2018)

Gansel LC, Rackebrandt S, Oppedal F, McClimans TA (2014) Flow fields inside stocked fish cages and the near environment. J Offshore Mech Arctic Eng 136:031201

Kansel LC, Oppedal F, Birkevold J, Tuene S (2018) Drag forces and deformation of aquaculture cages - full-scale towing tests in the field. Aquacult Eng 81:46-56

Gentry RR, Froehlich HE, Grimm D, Kareiva P and others (2017) Mapping the global potential for marine aquaculture. Nat Ecol Evol 1:1317-1324

Hansen TJ, Fjelldal PG, Folkedal O, Vågseth T, Oppedal F (2017) Effects of light source and intensity on sexual maturation, growth and swimming behaviour of Atlantic salmon in sea cages. Aquacult Environ Interact 9: 193-204

Holmer M (2010) Environmental issues of fish farming in offshore waters: perspectives, concerns and research needs. Aquacult Environ Interact 1:57-70

Hvas M, Oppedal F (2017) Sustained swimming capacity of Atlantic salmon. Aquacult Environ Interact 9:361-369

Hvas M, Folkedal O, Imsland A, Oppedal F (2017a) The effect of thermal acclimation on aerobic scope and critical swimming speed in Atlantic salmon, Salmo salar. J Exp Biol 220:2757-2764

*Hvas M, Folkedal O, Solstorm D, Vågseth T, Fosse JO, Gansel LC, Oppedal F (2017b) Assessing swimming capacity and schooling behaviour in farmed Atlantic salmon Salmo salar with experimental push-cages. Aquaculture 473:423-429

*Hvas M, Karlsbakk E, Mæhle S, Wright DW, Oppedal F (2017c) The gill parasite Paramoeba perurans compromises aerobic scope, swimming capacity and ion balance in Atlantic salmon. Conserv Physiol 5:cox066

*Hvas M, Folkedal O, Imsland A, Oppedal F (2018) Metabolic rates, swimming capabilities, thermal niche and stress response of the lumpfish, Cyclopterus lumpus. Biol Open 7:bio036079

* Imsland AK, Reynolds P, Eliassen G, Hangstad TA, Foss A, Vikingstad E, Elvegård TA (2014) The use of lumpfish (Cyclopterus lumpus L.) to control sea lice (Lepeophtheirus salmonis Krøyer) infestations in intensively farmed Atlantic salmon (Salmo salar L.). Aquaculture 424-425:18-23

Johansson D, Ruohonen K, Kiessling A, Oppedal F, Stiansen JE, Kelly M, Juell JE (2006) Effect of environmental factors on swimming depth preferences of Atlantic salmon (Salmo salar L.) and temporal and spatial variations in oxygen levels in sea cages at a fjord site. Aquaculture 254:594-605

Johansson D, Juell JE, Oppedal F, Stiansen JE, Ruohonen K (2007) The influence of the pycnocline and cage resistance on current flow, oxygen flux and swimming behaviour of Atlantic salmon (Salmo salar L.) in production cages. Aquaculture 265:271-287

Johansson D, Laursen F, Fernö A, Fosseidengen JE and others (2014) The interaction between water currents and salmon swimming behaviour in sea cages. PLOS ONE 9: e97635

Klebert P, Lader L, Gansel LC, Oppedal F (2013) Hydrodynamic interactions on net panel and aquaculture fish cages: a review. Ocean Eng 58:260-274

Klebert P, Patursson Ø, Endresen PC, Rundtop P, Birkevold J, Rasmussen HW (2015) Three-dimensional deformation of a large circular flexible sea cage in high currents: field experiment and modeling. Ocean Eng 104:511-520

Kristiansen T, Faltinsen OM (2012) Modelling of current loads on aquaculture net cages. J Fluids Structures 34: 218-235

* Lader P, Dempster T, Fredheim A, Jensen Ø (2008) Current induced net deformations in full-scale sea-cages for Atlantic salmon (Salmo salar). Aquacult Eng 38:52-65

\%Lader P, Kristiansen D, Alver M, Bjelland HV, Myrhaug D (2017) Classification of aquaculture locations in Norway with respect to wind wave exposure. Paper no. OMAE 2017-61659. In: Proc ASME 2017, 36th Int Conf Ocean, Offshore and Arctic Engineering, Trondheim. Vol 6: ocean space utilization. American Society of Mechanical Engineers (ASME), New York, NY, p V006T05A005

Løland G (1991) Current forces on and flow through fish farms. PhD dissertation, Norwegian University of Science and Technology, Trondheim

*Mayer DA, Virmani JI, Weisberg RH (2007) Velocity comparisons from upward and downward acoustic Doppler current profilers on the West Florida Shelf. J Atmos Ocean Technol 24:1950-1960

*NAS (Norsk Allmennstandardisering) (2009) NS-9415 Marine fish farms - requirements for site survey, risk analy- 
ses, design, dimensioning, production, installation and operation. ICS 65.150;67.260. Standards Norway, Oslo. www.standard.no (accessed 16 May 2018)

Oldham T, Dempster T, Fosse JO, Oppedal F (2017) Oxygen gradients affect behaviour of caged Atlantic salmon Salmo salar. Aquacult Environ Interact 9:145-153

Oppedal F, Dempster T, Stien LH (2011) Environmental drivers of Atlantic salmon behaviour in sea-cages: a review. Aquaculture 311:1-18

Plaut I (2001) Critical swimming speed: its ecological relevance. Comp Biochem Physiol A 131:41-50

Powell A, Treasurer JW, Pooley CL, Keay AJ, Lloyd R, Imsland AK, Garcia de Leaniz C (2017) Use of lumpfish for sea lice control in salmon farming: challenges and opportunities. Rev Aquacult 10:683-702

Remen M, Oppedal F, Imsland AK, Olsen RE, Torgersen T (2013) Hypoxia tolerance thresholds for post-smolt Atlantic salmon: dependency of temperature and hypoxia acclimation. Aquaculture 416-417:41-47

Remen M, Aas TS, Vågseth T, Torgersen T, Olsen RE, Imsland A, Oppedal F (2014) Production performance of Atlantic salmon (Salmo salar L.) postsmolts in cyclic hypoxia, and following compensatory growth. Aquacult Res 45:1355-1366

Remen M, Solstorm F, Bui S, Klebert P and others (2016) Critical swimming speed in groups of Atlantic salmon Salmo salar. Aquacult Environ Interact 8:659-664

Sætre R (ed) (2007) The Norwegian coastal current:

Editorial responsibility: Pablo Sánchez Jerez, Alicante, Spain oceanography and climate. Tapir Academic Press, Institute of Marine Research, Trondheim

SeaDataNet (2010) Data quality control procedures, version 2.0. www.seadatanet.org (accessed 28 May 2018)

Solstorm F, Solstorm D, Oppedal F, Fernö A, Fraser TWK, Olsen RE (2015) Fast water currents reduce production performance of post-smolt Atlantic salmon Salmo salar. Aquacult Environ Interact 7:125-134

* Solstorm D, Oldham T, Solstorm F, Klebert P, Stien LH, Vågseth T, Oppedal F (2018) Dissolved oxygen variability in a commercial sea-cage exposes farmed Atlantic salmon to growth limiting conditions. Aquaculture 486: 122-129

* Stehfest KM, Carter CG, McAllister JD, Ross JD, Semmens JM (2017) Response of Atlantic salmon Salmo salar to temperature and dissolved oxygen extremes established using animal-borne environmental sensors. Sci Rep 7:4545

Stien LH, Nilsson J, Hevrøy EM, Oppedal F, Kristiansen TS, Lien AM, Folkedal O (2012) Skirt around a salmon sea cage to reduce infestation of salmon lice resulted in low oxygen levels. Aquacult Eng 51:21-25

* Winthereig-Rasmussen H, Patursson Ø, Simonsen K (2015) Visualisation of the wake behind fish farming sea cages. Aquacult Eng 64:25-31

Winthereig-Rasmussen H, Simonsen K, Patursson Ø (2016) Flow through fish farming sea cages: comparing computational fluid dynamics simulations with scaled and full-scale experimental data. Ocean Eng 124:21-31

Submitted: November 16, 2018; Accepted: March 29, 2019

Proofs received from author(s): May 29, 2019 